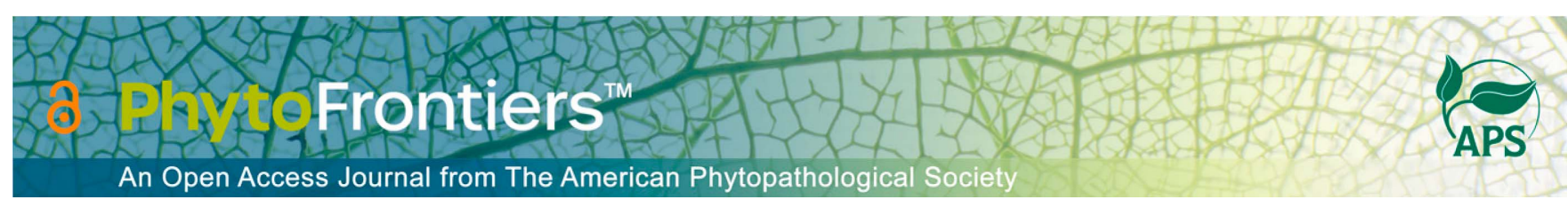

\title{
Research
}

\section{Insights into Detoxification of Tolaasins, the Toxins Behind Mushroom Bacterial Blotch, by Microbacterium foliorum NBRC $103072^{\top}$}

\author{
Shun Tomita $^{1}$ | Akinobu Kajikawa ${ }^{1}$ | Shizunobu Igimi ${ }^{1}$ | Hirosuke Shinohara ${ }^{2}$ | Kenji Yokota ${ }^{1,+}$ (i) |
}

1 Department of Agricultural Chemistry, Tokyo University of Agriculture, 1-1-1 Sakuragaoka, Setagaya, Tokyo 156-8502, Japan

2 Department of Agriculture, Tokyo University of Agriculture, 1737 Funako, Atsugi, Kanagawa 243-0034, Japan

† Corresponding author: K. Yokota; yokota@nodai.
ac.jp

Accepted for publication 25 March 2021

\section{Funding}

This work was supported by Tokyo NODA

Doctoral Research Grant Program (46404788F) to

S. Tomita, and Tokyo NODAI Research Program for Excellent Doctoral Students (46406956F) to K. Yokota.

$e$-Xtra: Supplementary materials are available online.

The author(s) declare no conflict of interest.

\begin{abstract}
Tolaasins are lipodepsipeptides secreted by Pseudomonas tolaasii, the causal agent of brown blotch disease of mushroom, and are the toxins that cause the brown spots. We previously reported that Microbacterium foliorum NBRC $103072^{\top}$ is an effective tolaasin-detoxifying bacterium. In this study, we aimed to characterize the tolaasin-detoxification process of $M$. foliorum NBRC $103072^{\top}$. The tolaasin detoxification by $M$. foliorum NBRC $103072^{\top}$ was carried out by hydrolyzation of tolaasins at two specific sites in the peptide moiety of tolaasins by its cells, and the resulting fragments were released from bacterial cells. The tolaasin-hydrolyzing activity can be extracted by a neutral detergent solution from M. foliorum NBRC $103072^{\top}$ cells. Moreover, tolaasin adsorption to the bacterial cells occurred prior to hydrolyzation of tolaasins, which might contribute to the effective tolaasin detoxification by $M$. foliorum NBRC $103072^{\top}$. It is notable that the tolaasin-degradation process by $M$. foliorum NBRC $103072^{\top}$ is carried out by hydrolyzation at specific sites in the peptide moiety of lipopeptide by bacterial cells as a novel biological degradation process of cyclic lipopeptides.
\end{abstract}

Keywords: biocontrol, lipodepsipeptide, Microbacterium foliorum, Pseudomonas tolaasii, tolaasin

Brown blotch on mushroom, caused by Pseudomonas tolaasii is a problematic disease in the mushroom industry that can cause large economic losses (Goor et al. 1986; Han et al. 2012; Osdaghi et al. 2019; Paine 1919; Thorn and Tsuneda 1996; Tolaas 1915). Tolaasins, which are cyclic lipodepsipeptides secreted by $P$. tolaasii, have been identified as the toxins responsible for the disease's characteristic symptoms; unappealing brown or cream-colored lesions on pileus and stipe on the fruiting bodies of a wide range of edible mushroom species (Brodey et al. 1991; Hutchison and Johnstone 1993; Soler-Rivas et al. 1999). Seven homologs of tolaasins-tolaasin I, II, A, B, C, D, and E (Fig. 1A and B)-have been identified thus far (Bassarello et al. 2004; Nutkins et al. 1991). All of the tolaasin homologs consist of an octadecyl peptide and a $\beta$-hydroxyl fatty acid, and all except tolaasin $\mathrm{C}$ have a cyclic structure within the peptide 
moiety by linkage between the hydroxyl group of $\mathrm{D}^{-T h r 14}$ and the C-terminal of ${ }_{\text {L-Lys18. Tolaasins (except tolaasin C) }}$ show antimicrobial activities against a broad range of fungi and Gram-positive bacteria (Bassarello et al. 2004), and the cyclic structure of tolaasins might be important for their antimicrobial activities.

We previously reported that a bacterial isolate, Microbacterium sp. K3-5 (K3-5), shows tolaasin-detoxifying activity by hydrolyzation of tolaasins at the linkage between the hydroxyl group of ${ }_{D^{-T}}$ Thr14 and the C-terminal of ${ }_{\mathrm{L}}$-Lys 18 (Tomita et al. 2018). We also demonstrated that tolaasins are directly hydrolyzed by bacterial cells of K3-5, whereas no hydrolyzing activity can be detected within K3-5 culture supernatants (Tomita et al. 2018). A few other reports have described inactivation of antimicrobial cyclic lipopeptides surfactin and daptomycin by Streptomyces strains (D'Costa et al. 2012; Hoefler et al. 2012). However, in those cases, the cyclic lipopeptide hydrolyzation was carried out by enzymes secreted by Streptomyces spp. into their culture supernatants.

We previously reported that all of the tested strains of Microbacterium spp. efficiently adsorb tolaasins, whereas no tolaasin-detoxifying activity can be detected in their culture supernatants. However, tolaasin adsorption onto Microbacterium cells is insufficient for tolaasin detoxification by most of the strains (Tomita et al. 2020).
Among the tested strains, we found that Microbacterium foliorum NBRC $103072^{\mathrm{T}}$ (M. foliorum 103072) and K3-5 both show tolaasin-detoxifying activity. When K3-5 detoxifies tolaasins, hydrolyzed tolaasins are released from $\mathrm{K} 3-5$ cells into the supernatant, where they can be detected by liquid chromatography mass spectrometry (LC-MS) (Tomita et al. 2018). On the other hand, although M. foliorum 103072 detoxifies tolaasins as well as K3-5, no hydrolyzed tolaasins can be detected in the $M$. foliorum 103072 supernatants (Tomita et al. 2020), suggesting that the tolaasin-detoxification process by M. foliorum 103072 cells might differ from K3-5. Therefore, in this study, we aimed to characterize the tolaasin-detoxification process of M. foliorum 103072.

\section{MATERIALS AND METHODS}

\section{Strains and medium}

P. tolaasii 814, the causal agent of bacterial brown blotch on mushroom, was used for purification of tolaasins. M. foliorum NBRC $103072^{\mathrm{T}}$ (Behrendt et al. 2001) was used as a tolaasindetoxifying strain (Tomita et al. 2020). Strains were kept as glycerol stocks at $-80^{\circ} \mathrm{C}$ until use. King's B medium $(2.0 \%$ Proteose peptone, $0.15 \% \mathrm{~K}_{2} \mathrm{HPO}_{4}, 0.15 \% \mathrm{MgSO}_{4} \cdot 7 \mathrm{H}_{2} \mathrm{O}$, and

A

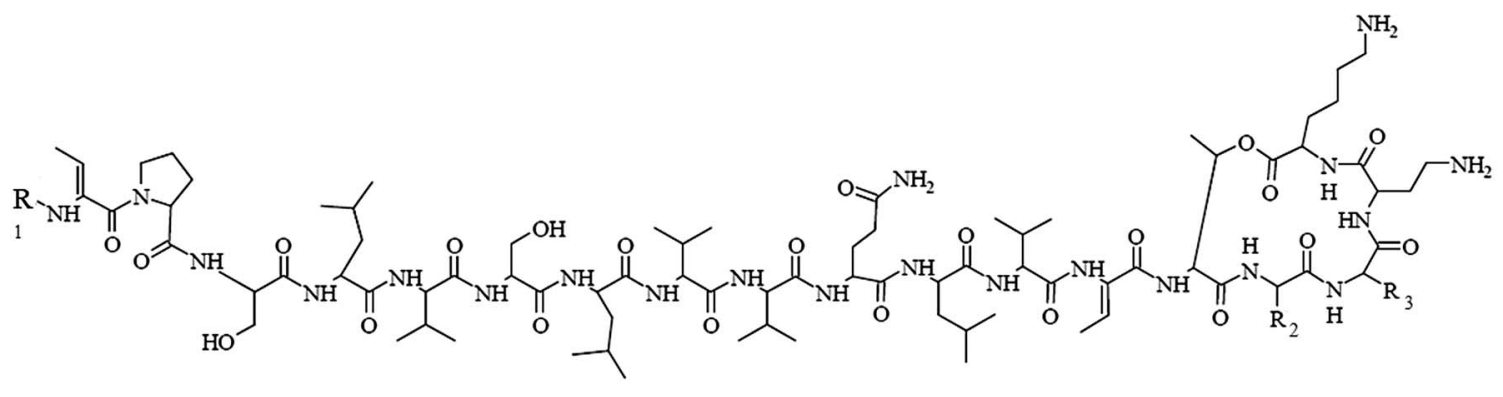

Tolaasin I Tolaasin II Tolaasin A Tolaasin B Tolaasin D Tolaasin E
$\mathrm{R}_{1}=\mathrm{COCH}_{2} \mathrm{CH}(\mathrm{OH}) \mathrm{CH}_{2}\left(\mathrm{CH}_{2}\right)_{3} \mathrm{CH}_{3}, \mathrm{R}_{2}=\mathrm{CH}\left(\mathrm{CH}_{3}\right) \mathrm{CH}_{2} \mathrm{CH}_{3}, \mathrm{R}_{3}=\mathrm{CH}_{2} \mathrm{CH}_{2} \mathrm{OH}$

$\mathrm{R}_{1}=\mathrm{COCH}_{2} \mathrm{CH}(\mathrm{OH}) \mathrm{CH}_{2}\left(\mathrm{CH}_{2}\right)_{3} \mathrm{CH}_{3}, \mathrm{R}_{2}=\mathrm{CH}\left(\mathrm{CH}_{3}\right) \mathrm{CH}_{2} \mathrm{CH}_{3}, \mathrm{R}_{3}=\mathrm{H}$

$\mathrm{R}_{1}=\mathrm{CO}\left(\mathrm{CH}_{2}\right)_{3} \mathrm{COOH}, \mathrm{R}_{2}=\mathrm{CH}\left(\mathrm{CH}_{3}\right) \mathrm{CH}_{2} \mathrm{CH}_{3}, \mathrm{R}_{3}=\mathrm{CH}_{2} \mathrm{CH}_{2} \mathrm{OH}$

$\mathrm{R}_{1}=\mathrm{COCH}_{2} \mathrm{CH}(\mathrm{OH}) \mathrm{CH}_{2}\left(\mathrm{CH}_{2}\right)_{3} \mathrm{CH}_{3}, \mathrm{R}_{2}=\mathrm{CH}\left(\mathrm{CH}_{3}\right)_{2}, \mathrm{R}_{3}=\mathrm{CH}_{2} \mathrm{CH}_{2} \mathrm{OH}$

$\mathrm{R}_{1}=\mathrm{COCH}_{2} \mathrm{CH}(\mathrm{OH}) \mathrm{CH}_{2}\left(\mathrm{CH}_{2}\right)_{3} \mathrm{CH}_{3}, \mathrm{R}_{2}=\mathrm{CH}_{2} \mathrm{CH}\left(\mathrm{CH}_{3}\right)_{2}, \mathrm{R}_{3}=\mathrm{CH}_{2} \mathrm{CH}_{2} \mathrm{OH}$

$\mathrm{R}_{1}=\mathrm{COCH}_{2} \mathrm{CH}(\mathrm{OH}) \mathrm{CH}_{2}\left(\mathrm{CH}_{2}\right)_{3} \mathrm{CH}_{3}, \mathrm{R}_{2}=\mathrm{CH}_{2} \mathrm{CH}\left(\mathrm{CH}_{3}\right)_{2}, \mathrm{R}_{3}=\mathrm{H}$

B

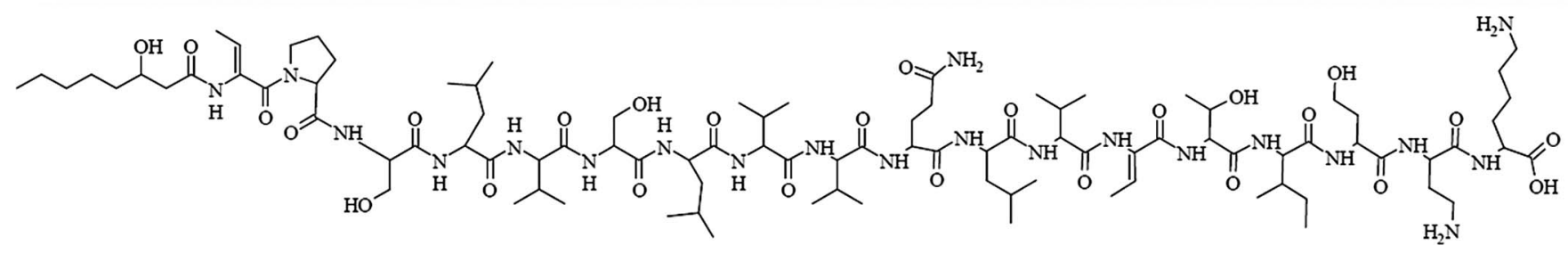

FIGURE 1

Chemical structure of tolaasin. A, Tolaasin I, II, A, B, D, and E; B, Tolaasin C. 
$1.0 \%$ glycerol) was used for all bacterial cultivations (King et al. 1954).

\section{Purification of tolaasins}

Tolaasins were purified from bacterial cultures of $P$. tolaasii 814 as described previously (Tomita et al. 2020). Briefly, weakly acidic cation exchange resin (DIAION WK11; Mitsubishi Chemical, Tokyo, Japan) was added to the culture supernatants of $P$. tolaasii 814. After vigorous shaking, the resin was collected and washed by methanol $(\mathrm{MeOH})$; then, tolaasins were eluted by $\mathrm{MeOH}$ containing $1.0 \%$ (vol/vol) formic acid. The elution was dried up in a rotary evaporator (N-1110; Tokyo Rikakikai, Tokyo, Japan). The resulting residue was dissolved in $50 \%$ (vol/vol) $\mathrm{MeOH}$ and applied onto an ODS column (Purif-pack ODS $100 \mu \mathrm{m}$ size: 60; Shoko Scientific, Yokohama, Japan). After washing the column with $50 \%$ (vol/vol) $\mathrm{MeOH}$, tolaasins were eluted by $\mathrm{MeOH}$ containing $0.1 \%$ (vol/vol) formic acid.

\section{LC-electrospray ionization tandem mass spectrometry analysis}

For identification of tolaasin-degradation products, electrospray ionization tandem mass spectrometry (ESI-MS/MS) coupled with collision induced dissociation and the collision gas helium were used for further identification of the amino acid sequence of degraded tolaasin products. The selected precursor ions were acquired in auto LC-ESI-MS/MS modalities; then, the data were analyzed by using accurate-mass quadrupoletime-of-flight LC/MS with Agilent 6530 (Agilent Technologies, Santa Clara, CA, U.S.A.). Chromatographic separation was achieved using an Inert Sustain AQ-C18 (3 $\mu \mathrm{m}, 1.0$ by $150 \mathrm{~mm}$; GL Sciences, Tokyo, Japan). The gradient had a constant flow rate of $0.07 \mathrm{ml} / \mathrm{min}$, with solvent $\mathrm{A}=$ ultrapure water (UPW) containing $0.1 \%$ ( $\mathrm{vol} / \mathrm{vol}$ ) formic acid and solvent $\mathrm{B}=$ acetonitrile containing $0.1 \%$ ( $\mathrm{vol} / \mathrm{vol})$ formic acid. The linear gradient timetable consisted of $0 \mathrm{~min}, 70: 30$ $(\% \mathrm{~A} / \% \mathrm{~B})$; at $1 \mathrm{~min}, 70: 30$; at $13 \mathrm{~min}, 0: 100$; and at $15 \mathrm{~min}$, $0: 100$. These data were analyzed using the Agilent Mass Hunter Qualitative Analysis Software (version B. 06.00).

\section{LC-MS analysis}

Quantification of tolaasins and tolaasin-degradation products was performed by an LC-MS system (Infinity II 1260 HPLC) coupled to a single quadrupole mass spectrometer (Agilent Infinity Lab LC-MSD) (Agilent Technologies, Tokyo, Japan) equipped with atmospheric pressure ionization electrospray operated in the positive mode. Chromatographic separation was achieved using an Inert Sustain C18 column (UP $2 \mu \mathrm{m}$, 2.1 by $100 \mathrm{~mm}$; GL Sciences, Tokyo, Japan). The gradient had a constant flow rate of $0.4 \mathrm{ml} / \mathrm{min}$, with solvent $\mathrm{A}=\mathrm{UPW}$ containing $0.1 \%$ (vol/vol) formic acid and solvent $\mathrm{B}=$ acetonitrile containing $0.1 \%$ (vol/vol) formic acid. The linear gradient timetable consisted of $0 \mathrm{~min}, 80: 20(\% \mathrm{~A} / \% \mathrm{~B})$; at $4 \mathrm{~min}$, 48:52; and at $12 \mathrm{~min}, 48: 52$.

\section{Sample preparation for tolaasin I elimination and degradation assays}

Cell suspension. M. foliorum 103072 was grown in King's B medium at $25^{\circ} \mathrm{C}$ for $48 \mathrm{~h}$ with shaking at $130 \mathrm{rpm}$. Bacterial cells were obtained by centrifugation and suspended in phosphate-buffered saline (PBS) $(10 \mathrm{mM}$ phosphate-Na buffer [pH 6.8] and $140 \mathrm{mM} \mathrm{NaCl}$ ) at an optical density at $600 \mathrm{~nm}$ of $1.0\left(1.1 \times 10^{9}\right.$ cells $\left./ \mathrm{ml}\right)$.

Cell extract. Bacterial cells were obtained from $500 \mathrm{ml}$ of shaking culture of $M$. foliorum 103072 grown as described above by centrifugation and washed by PBS twice. According to van der Woude et al. (2013), $10 \mathrm{ml}$ of Triton X-100 in 10 $\mathrm{mM}$ sodium phosphate buffer $(\mathrm{pH}$ 7.2) was used for extraction of membrane proteins from bacterial cells $\left(2.0 \times 10^{11}\right.$ cells $)$ for $2 \mathrm{~h}$ at $4{ }^{\circ} \mathrm{C}$. After incubation, the supernatant was obtained by centrifugation at $10,000 \times g$ for $10 \mathrm{~min}$ and filtrated by cellulose acetate membrane (DISMIC-25CS, $0.20 \mu \mathrm{m}$; Advantec, Tokyo, Japan).

\section{Tolaasin I elimination and degradation assays}

Elimination assay. Purified tolaasin ( $5 \mu 1,2 \mathrm{mg} / \mathrm{ml})$ was added to $120 \mu \mathrm{l}$ of the cell suspension and incubated for $4 \mathrm{~h}$ at $25^{\circ} \mathrm{C}$. After incubation, $120 \mu \mathrm{l}$ of the supernatant was obtained by centrifugation at $10,000 \times g$ for $5 \mathrm{~min}$ and $80 \mu \mathrm{l}$ of $\mathrm{MeOH}$ was added to culture supernatants for LC-MS analysis, followed by filtration by cellulose acetate membrane (DISMIC03CP $0.45 \mu \mathrm{m}$; Advantec).

Degradation assay. Purified tolaasin $(5 \mu \mathrm{l}, 2 \mathrm{mg} / \mathrm{ml})$ was added to $120 \mu \mathrm{l}$ of crude enzyme extracts and incubated for 4 $\mathrm{h}$ at $25^{\circ} \mathrm{C}$. After incubation, $80 \mu \mathrm{l}$ of $\mathrm{MeOH}$ was added to the crude enzyme extracts. To confirm the tolaasin degradation, LC-MS analysis was performed as described above.

\section{Tolaasin elimination and degradation assay on the different $\mathrm{pH}$ condition}

Cell suspension. Cell suspensions of M. foliorum 103072 were prepared as described above and resuspended by $120 \mu \mathrm{l}$ of $40 \mathrm{mM}$ Britton-Robinson buffer ( $40 \mathrm{mM}$ boric acid, 40 $\mathrm{mM}$ acetic acid, and $40 \mathrm{mM}$ phosphoric acid; $\mathrm{pH}$ was adjusted by $\mathrm{NaOH}$ ) (Britton and Robinson 1931). The $\mathrm{pH}$ of BrittonRobinson buffer solution ranged from 4 to 9 . Purified tolaasin ( $5 \mu \mathrm{l}, 2 \mathrm{mg} / \mathrm{ml}$ ) was added to $120 \mu \mathrm{l}$ of bacterial suspension with each $\mathrm{pH}$ buffer and incubated for $1 \mathrm{~h}$ at $25^{\circ} \mathrm{C}$. Sample preparation and LC-MS analysis were performed as described above. Tolaasin I and tolaasin-degradation products $(\mathrm{m} / \mathrm{z}, 727$ $\left.[\mathrm{M}+\mathrm{H}]^{+}\right)$in the treatment with cell suspension and crude enzyme were quantified by LC-MS. The percentage of elimination of tolaasin I was calculated as follows:

Tolaasin I elimination $(\%)=100-$

$\{[$ Peak area of tolaasin I (treatment of cell suspensions)]/

$[$ Peak area of tolaasin I (control) $]\} \times 100$

Cell extracts. Bacterial cells were obtained by centrifugation from 1 liter of shaking culture of M. foliorum 103072 and washed by UPW twice. The cell pellets were resuspended in $10 \mathrm{ml}$ of $0.5 \%$ TritonX-100 and incubated for $2 \mathrm{~h}$ at $4^{\circ} \mathrm{C}$. After incubation, the crude enzyme extracts were obtained by centrifugation at $10,000 \times g$ for $10 \mathrm{~min}$ and filtrated by cellulose acetate membrane (DISMIC-25CS $0.20 \mu \mathrm{m}$; Advantec). Crude enzyme extracts $(60 \mu \mathrm{l}$ each) were twofold diluted with $80 \mathrm{mM}$ Britton Robinson buffer at $\mathrm{pH} 4$ to 9 . Purified tolaasin ( $5 \mu \mathrm{l}, 2 \mathrm{mg} / \mathrm{ml}$ ) was added to $120 \mu \mathrm{l}$ of the crude enzymes with each $\mathrm{pH}$ buffer and incubated for $5 \mathrm{~h}$ at $25^{\circ} \mathrm{C}$. Sample preparation and LC-MS analysis were performed as described above. The percentage of elimination of tolaasin I was calculated as described above. 


\section{DNA extraction and amplification}

The supernatant of cell lysate and the cell extracts described above were used as PCR template for detection of $16 \mathrm{~S}$ ribosomal RNA (rRNA). Cell extracts were obtained as described above. The supernatant of cell lysate was obtained from the cell pellet collected by the extraction with $0.5 \%$ TritonX-100. After the cell pellet was resuspended with PBS, 0.2-mm-diameter Zirconia/Silica Beads (Bio Medical Science, Tokyo, Japan) were added to $200 \mu \mathrm{l}$ of the suspension and disrupted by a cell homogenizer (FastPrep 24 Instrument; Funakoshi, Tokyo, Japan) for $2 \mathrm{~min}$. After the disruption of the cells, the supernatant was collected by centrifugation at $10,000 \times g$ for $10 \mathrm{~min}$.

The cell extracts and supernatant of cell lysate were 1,000fold diluted with UPW.

The 16S rRNA was amplified from the diluted samples by PCR using a set of universal bacterial primers for $16 \mathrm{~S}$ rRNA gene: 27F (5'-AGAGTTTGATCCTGGCTCAG-3') and 1492R (5'-CGGTTACCTTGTTACGACTT-3'). The PCR amplicons were electrophoresed on a $1 \%$ agarose gel with $1 \times$ Tris-acetateEDTA buffer ( $50 \mathrm{mM}$ Tris-base, $30 \mathrm{mM}$ sodium acetate, and 3 mM EDTA in UPW; pH adjusted to 7.8 with $96 \%$ acetic acid). The gels were stained in ethidium bromide $(1 \mu \mathrm{g} / \mathrm{ml})$ and visualized with the Bio-Rad ChemiDoc XRS+ system (Bio-Rad Laboratories, Hercules, CA, U.S.A.). Semiquantification of PCR amplicons of $16 \mathrm{~S}$ rRNA gene was performed by ImageJ image analysis software (http://rsbweb.nih.gov/ij/index.html).

\section{Statistical analysis}

The data were analyzed by one-way analysis of variance followed by Tukey's honestly significant difference post hoc test or Student's $t$ test with the freely available statistical analysis program tool js-STAR (version 9.1.8j; Tanaka and Nappa) and differences were considered to be significant at $P<0.05$.

\section{RESULTS}

\section{Hydrolyzation of tolaasins by M. foliorum 103072 cells}

Four novel mass peaks of $m / z, 727,640,640$, and 683 were detected by LC-MS in the supernatants derived from purified tolaasins added to M. foliorum 103072 cell suspension (Fig. 2B), whereas they were not detected in the purified tolaasins (Fig. 2A).

The $\mathrm{MS}^{2}$ spectrum of the parent ion of protonated molecule $[\mathrm{M}+\mathrm{H}]^{+}$at $m / z, 727.43$ showed a set of daughter ions (Fig. 3A). Successive fragmentations from the two termini of the $\mathrm{m} / \mathrm{z}$ 727.43 resulted in b-type ions at $\mathrm{m} / \mathrm{z} 622.35,523.30\left(-\mathrm{H}_{2} \mathrm{O}\right.$, 505.27), 410.21, 323.17, and 226.14 along with corresponding y-type ions detected at $m / z 502.27\left(-\mathrm{H}_{2} \mathrm{O}, 484.25\right), 405.23$, 318.20 , and 205.12. These fragment ions were assigned to the sequence of $\beta$-hydroxyoctanoic acid chain- $\Delta$ but1-Pro2-Ser3Leu4-Val5-Ser6, which corresponds to the N-terminal fragment derived from hydrolyzation of tolaasin $\mathrm{I}$ at the position of Ser6 and Leu7. The $\mathrm{MS}^{2}$ spectrum of the parent ion of protonated molecule $[\mathrm{M}+2 \mathrm{H}]^{2+}$ at $\mathrm{m} / \mathrm{z}, 639.91$ were assigned to the fragment of Leu1-Val2-Val3-Gln4-Leu5-Val6- $\Delta$ but7-Thr8Ile9-Hse10-Dab11-Lys12 cyclized via lactone formation between Thr8 and the $\mathrm{C}$ terminus, which corresponds to the C-terminal fragment derived from hydrolyzation of tolaasin I at the position of Ser7 and Leu8 (Fig. 3B).

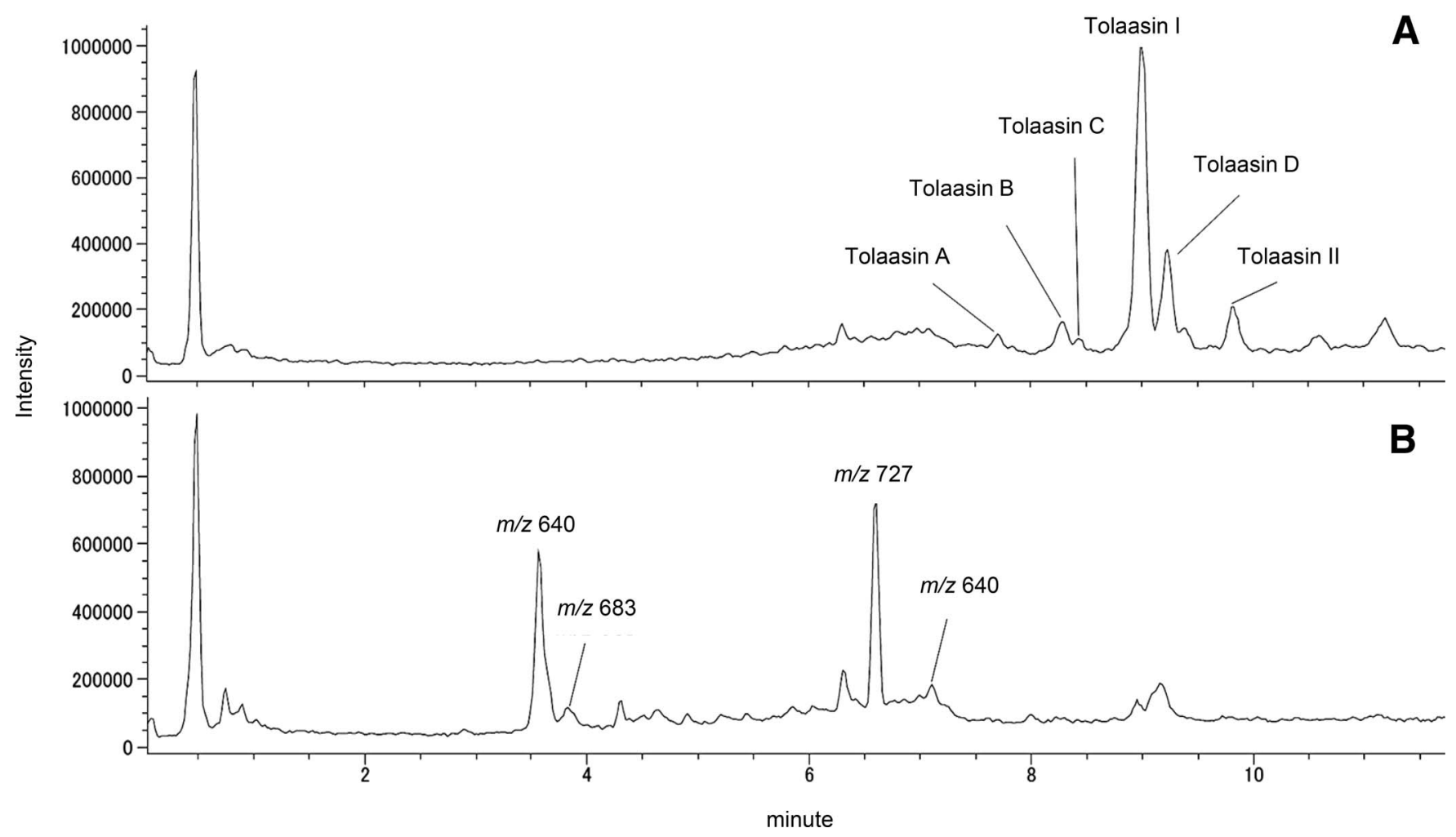

FIGURE 2

Total ion chromatogram of tolaasins. A, Purified tolaasins treated in just phosphate-buffered saline. Masses $(\mathrm{m} / \mathrm{z})$ of peaks A, B, C, I, D, and II are 980, 987, 1,003, 994, 994, and 972, respectively. B, Microbacterium foliorum 103072-treated tolaasin. Masses ( $\mathrm{m} / \mathrm{z}$ ) of novel peaks are 640,727 , and 683. 
The other $\mathrm{MS}^{2}$ spectrum of the parent ions of protonated ion $[\mathrm{M}+\mathrm{H}]^{+}$at $m / z 640.39$ and $[\mathrm{M}+2 \mathrm{H}]^{2+}$ at 683.43 was assigned to $\beta$-hydroxyoctanoic acid chain- $\Delta$ but1-Pro2-Ser3-Leu4-Val5 and Ser1-Leu2-Val3-Val4-Gln5-Leu6-Val7- $\Delta$ but8-Thr9-Ile10-Hse11Dab12-Lys13 cyclized via lactone formation between Thr9 and the $\mathrm{C}$ terminus, respectively, and correspond to the N-terminal and C-terminal of tolaasin I when hydrolyzed at the position of Val5 and Ser6, respectively (Fig. 3C and D).

\section{Hydrolyzation of tolaasins by bacterial cell extracts}

Tolaasin hydrolyzation was observed from extracts of $M$. foliorum 103072 bacterial cells treated with Triton X-100 solution, whereas no tolaasin hydrolyzation was observed in the extract without Triton X-100 (Supplementary Fig. S1). Among the tested range of concentrations of Triton X-100 from 0 to $2 \%$, tolaasin hydrolyzation was significantly higher from 0.05 to $0.5 \%$. Therefore, we used $0.5 \%$ Triton $\mathrm{X}-100$ to prepare the bacterial cell extracts for further analyses in this study. When tolaasins were added to these cell extracts, the distinctive peaks of $m / z, 727[\mathrm{M}+\mathrm{H}]^{+}, 640[\mathrm{M}+2 \mathrm{H}]^{2+}, 640[\mathrm{M}+\mathrm{H}]^{+}$, and $683[\mathrm{M}+2 \mathrm{H}]^{2+}$, which correspond to the hydrolyzation products of tolaasin I at the position of Ser6 and Leu7 or Val5 and Ser6, were detected in the extracts as well as the supernatants, respectively (Supplementary Fig. S2).

To estimate the damage to bacterial cells by the $0.5 \%$ Triton X-100 treatment, we used PCR to amplify the 16S rRNA gene in the supernatants of $0.5 \%$ Triton $\mathrm{X}-100$ treatment and the cell lysate. The amount of 16S rRNA gene fragments detected by PCR was much lower in the supernatants of $0.5 \%$ Triton X-100 treatment compared with the supernatants of the cell lysate (Fig. 4).

\section{Characterization of tolaasin detoxification by the bacterial cell extract compared with the bacterial cell suspension}

In the cell suspension of M. foliorum 103072 (Fig. 5A), the amount of tolaasin I remaining in the supernatant rapidly decreased within $5 \mathrm{~min}$ (corresponding to approximately $60 \%$ of added tolaasin I). The ions of $[\mathrm{M}+\mathrm{H}]^{+}$of $\mathrm{m} / \mathrm{z}, 727$ and $[\mathrm{M}+2 \mathrm{H}]^{2+}$ of $\mathrm{m} / \mathrm{z} 640$, which correspond to the N-terminal fragment of tolaasin I, II, A, B, and D and the C-terminal fragment of tolaasin I, A, and D when hydrolyzed at Ser6 and Leu7, increased linearly and reached a plateau at $45 \mathrm{~min}$.

On the other hand, in bacterial cell extracts (Fig. 5B), added tolaasin I decreased linearly. The hydrolyzed products of $[\mathrm{M}+\mathrm{H}]^{+}$of $\mathrm{m} / \mathrm{z} 727$ and $[\mathrm{M}+2 \mathrm{H}]^{2+}$ of $\mathrm{m} / \mathrm{z}, 640$ also increased linearly in the bacterial cell extract, and did not reach a plateau even after $5 \mathrm{~h}$ of incubation (Fig. 5B).

We also measured the levels of tolaasin I and its hydrolyzed products in the supernatants of cell suspensions and the bacterial cell extract at different $\mathrm{pH}$ values (Fig. 6), whereas we didn't observe any hydrolyzed products in the absence of the cell suspension or cell extract across the same $\mathrm{pH}$ range (data not shown).

Levels of tolaasin I decreased more rapidly at a higher $\mathrm{pH}$ in the supernatants of cell suspension and bacterial cell extracts (Fig. 6A and B). Tolaasin hydrolyzed products also accumulated more rapidly at higher $\mathrm{pH}$ in the cell suspension and bacterial cell extracts (Fig. 6C and D), whereas levels of tolaasin I decreased. These results showed that rapid hydrolyzation of tolaasins was observed at higher $\mathrm{pH}$ in both cell suspensions and bacterial cell extracts. On the other hand, it was notable that, although $36 \%$ of tolaasin I was eliminated in the cell suspensions at $\mathrm{pH} 4$ (Fig. 6A), very little of the hydrolyzed products were observed (Fig. 6C).
A

$m / 2727.43[\mathrm{M}+\mathrm{H}]^{+}$

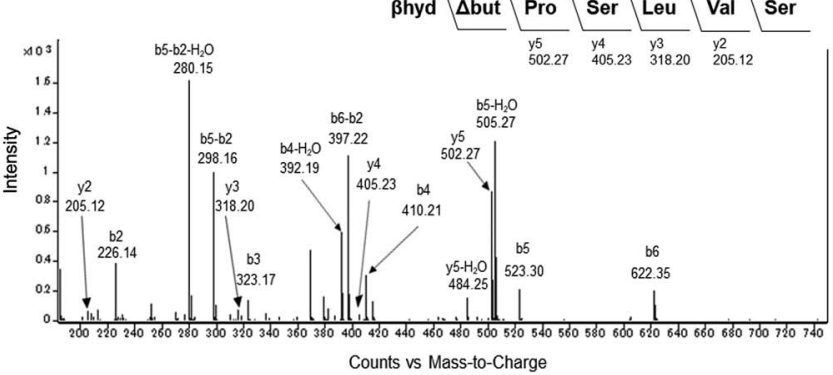

Counts vs Mass-to-Charge

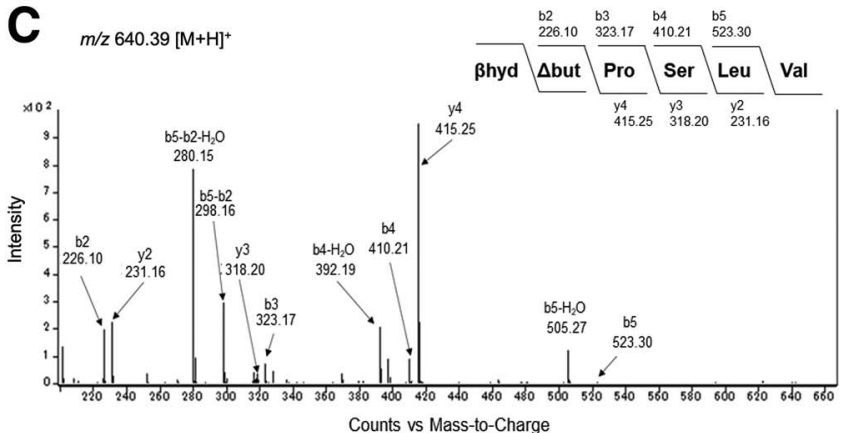

B $m / z 639.91[\mathrm{M}+2 \mathrm{H}]^{2+}$
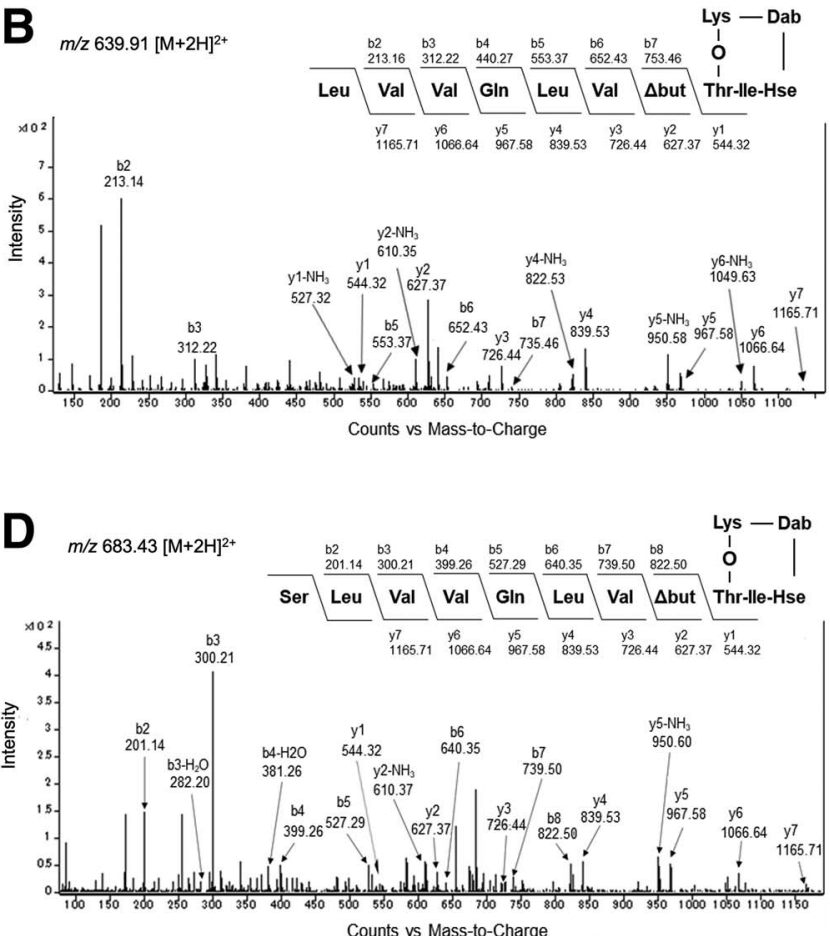

FIGURE 3

Liquid chromatography tandem mass spectrometry spectrum of tolaasins hydrolyzed by Microbacterium foliorum 103072 . A, $\mathrm{m} / \mathrm{z}$ 727.43[M+H] ${ }^{+}$; B, $m / z$ 639.91 $[\mathrm{M}+2 \mathrm{H}]^{2+} ; \mathbf{C}, m / z$ 640.39[M+H $]^{+}$; and $\mathbf{D}, m / z 683.43[\mathrm{M}+2 \mathrm{H}]^{2+}$. 


\section{DISCUSSION}

We previously reported that the ability to adsorb tolaasins is widely distributed among Microbacterium spp. but that tolaasin adsorption alone is insufficient for tolaasin detoxification (Tomita et al. 2020). Among the tested strains, we found that a few strains, including the bacterial isolate K3-5, showed significant tolaasin detoxification activity. We previously revealed that the mode of tolaasin detoxification by K3-5 was through hydrolyzation of tolaasins at the lactone ring between the hydroxyl group of the D-Thr14 and the C-terminal L-Lys18 (Tomita et al. 2018). Our previous data suggested that $M$. foliorum 103072 might have a novel tolaasin-detoxification mechanism on its cells. Hence, in this study, we aimed to clarify the mechanisms of tolaasin detoxification by $M$. foliorum 103072.

LC-MS/MS analysis revealed that M. foliorum 103072 cells hydrolyzed the peptide moiety of tolaasins at two specific peptide bonds of Ser6-Leu7 and Val5-Ser6, and the resulting fragments were released from the bacterial cells into supernatants (Fig. 3).

A few other articles have reported about inactivation of antimicrobial cyclic lipopeptides. The inactivation of the antimicrobial cyclic lipodepsipeptides surfactin and daptomycin by Streptomyces strains is carried out by linearization of the cyclic structures of cLPs by secreted hydrolases (D'Costa et al. 2012; Hoefler et al. 2012). It is notable that the detoxification of tolaasins by K3-5 and M. foliorum 103072 is carried out by the cells themselves and not by secreted hydrolases, and then the resulting products are released from the cells (Tomita et al. 2020) (Figs. 2 and 3).

Recently, Hermenau et al. (2020) reported tolaasin detoxification by bacterial isolates of Mycetocola spp. The tolaasin detoxification by bacterial isolates of Mycetocola spp. was carried out by hydrolyzation at the lactone ring as well as K3-5, which was previously reported (Tomita et al. 2020). Mycetocola sp. is a member of the family Microbacteriaceae along with Microbacterium sp., suggesting that the tolaasindetoxification process of K3-5 and Mycetocola spp. might be
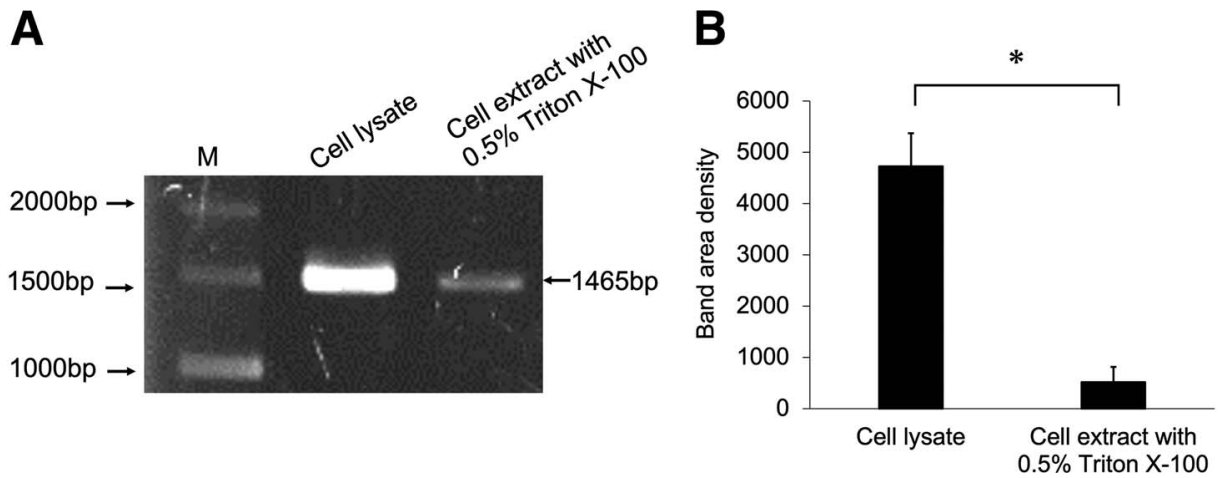

FIGURE 4

Estimation of the damage to bacterial cells by the $0.5 \%$ Triton X-100 treatment. A, Agarose gel image of DNA products from PCR of $16 \mathrm{~S}$ ribosomal RNA (rRNA) gene. B, Semiquantitative graph of DNA products from PCR of $16 \mathrm{~S}$ rRNA gene. Mean \pm standard error is represented $(n=3)$. An asterisk $\left({ }^{*}\right)$ denotes a significant difference with $P<0.05$ by Student's $t$ test.

A

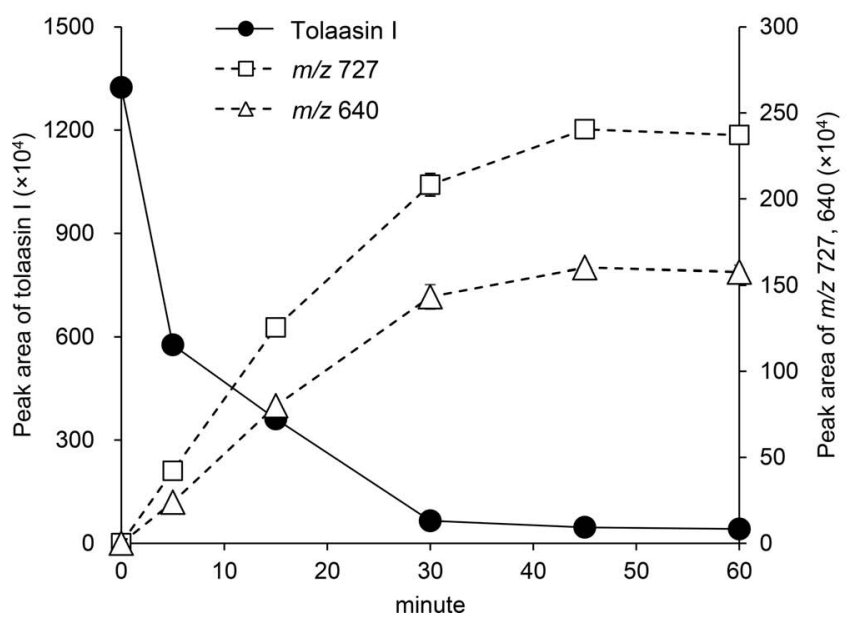

B Bacterial cell extract

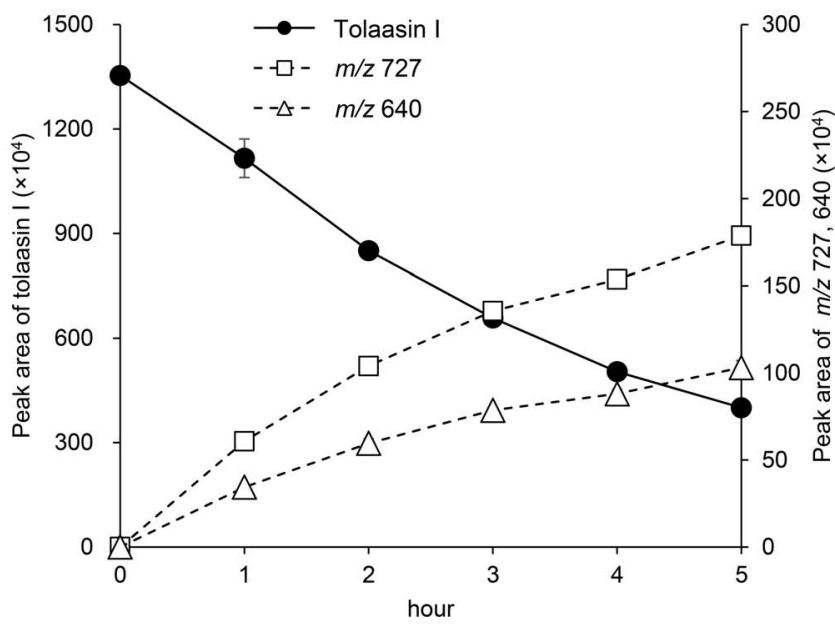

FIGURE 5

Time-course analysis of tolaasin elimination and hydrolyzation. Black circles represent peak area of tolaasin I and white squares and triangles represent peak area of $m / z 727[\mathrm{M}+\mathrm{H}]^{+}$and $m / z 640[\mathrm{M}+2 \mathrm{H}]^{2+}$, respectively. $\mathbf{A}$, Treatment by cell suspension and $\mathbf{B}$, treatment by bacterial cell extract. Mean \pm standard error is represented $(n=3)$. 
distributed in Microbacteriaceae. In this study, we found a novel tolaasin-hydrolyzation process on M. foliorum 103072 which was carried out by cleavages at the two site-specific peptide bonds.

The site-specific tolaasin-hydrolyzing activities of $M$. foliorum 103072 could be observed in the extracts from $M$. foliorum 103072 cells treated with Triton X-100 (Supplementary Fig. S2). In these bacterial cell extracts, genomic DNA was detected at a much lower level compared with the cell lysate supernatant
(Fig. 4), suggesting that tolaasin-hydrolyzing enzymes are localized in the bacterial cell wall.

In the previous study, although only a few strains show tolaasin detoxification, we observed that effective tolaasin adsorption was widely distributed among Microbacterium spp. (Tomita et al. 2020), suggesting that the factors responsible for tolaasin adsorption might exist independently from tolaasin-detoxifying factors. Hence, in this study, we conducted a comparative study of tolaasin hydrolyzation and its
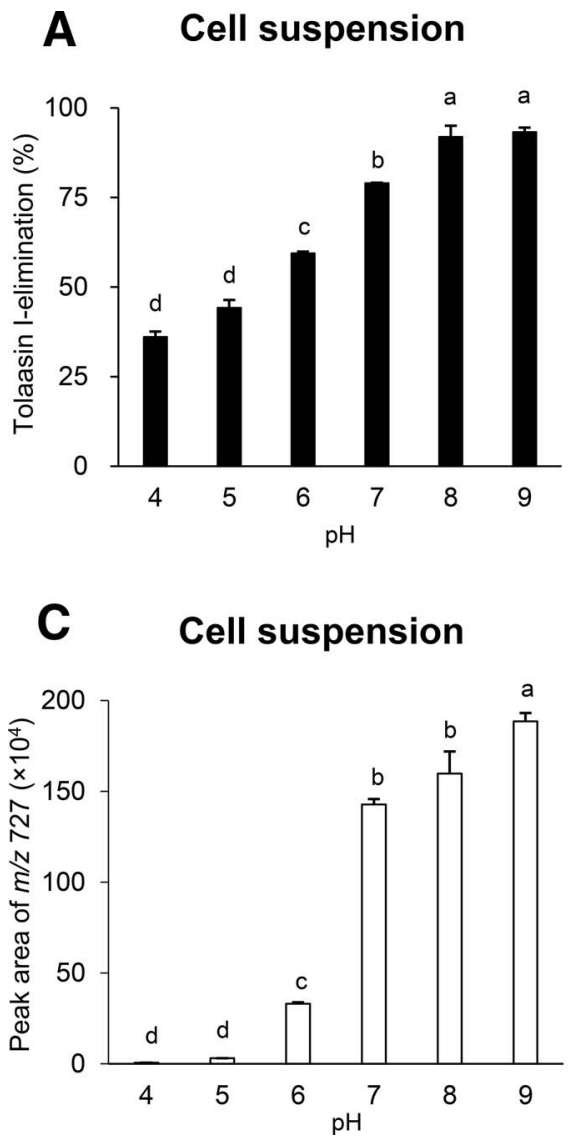

\section{B Bacterial cell extracts}

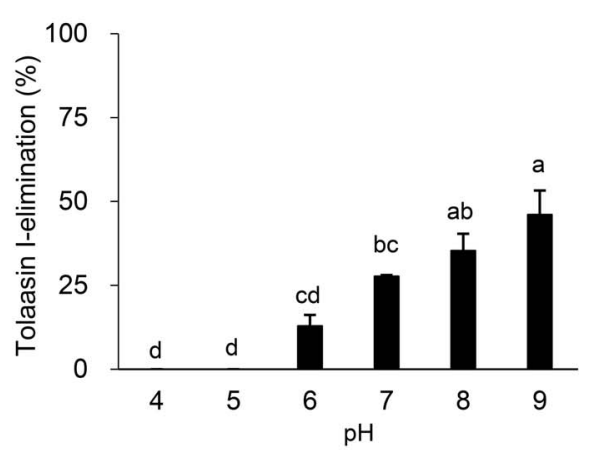

D Bacterial cell extracts

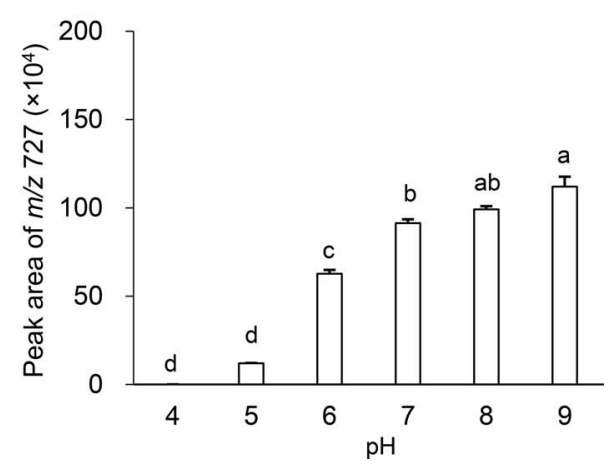

FIGURE 6

Tolaasin I elimination and hydrolyzation under the different $\mathrm{pH}$ conditions. Tolaasin I elimination: A, treatment by cell suspension and B, treatment by bacterial cell extract. Tolaasin-I hydrolyzation: $\mathbf{C}$, treatment by cell suspension and $\mathbf{D}$, treatment by bacterial cell extract. Mean + standard error is represented $(n=3)$. Values followed by different letters within the column are significantly different at $P<0.05$ level of confidence according to Tukey's test.

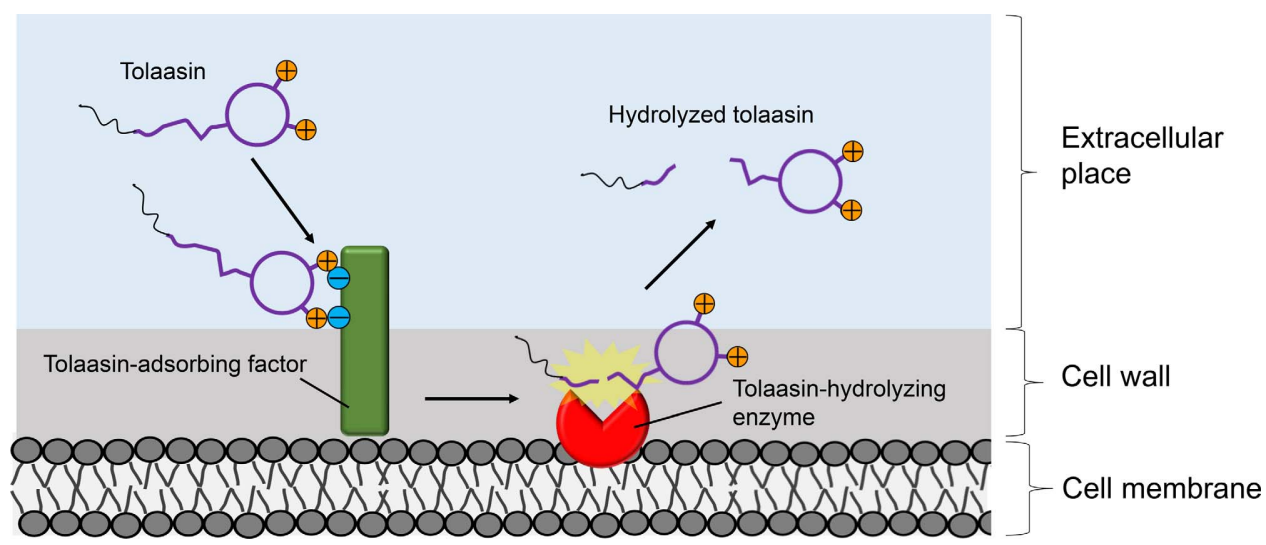

FIGURE 7

Hypothesis of tolaasin detoxification by Microbacterium foliorum 103072. 
elimination from bacterial cell suspensions and bacterial cell extracts (Fig. 5A and B). When added to the bacterial cell extracts, tolaasin I decreased linearly while the hydrolyzed tolaasin products $\left(\mathrm{m} / \mathrm{z}, 727[\mathrm{M}+\mathrm{H}]^{+}\right.$and $\left.640[\mathrm{M}+2 \mathrm{H}]^{2+}\right)$ increased inversely with the decreasing tolaasin I (Fig. 5B), suggesting that tolaasin degradation does not follow first-order kinetics. On the other hand, approximately $60 \%$ of tolaasin I rapidly decreased within 5 min when added to the supernatants of bacterial cell suspension whereas hydrolyzed tolaasin products linearly increased and reached a plateau after $45 \mathrm{~min}$ (Fig. 5A). These data strongly suggest that the factors for tolaasin adsorption are located in the bacterial cell wall. Moreover, these adsorption factors might be important for the effective detoxification of tolaasins by M. foliorum 103072 .

For further characterization of the bacterial cell suspensions and bacterial cell extracts, we evaluated tolaasin adsorption and hydrolyzation at a range of $\mathrm{pH}$ values (Fig. 6). Tolaasin I hydrolyzation was more active at $\mathrm{pH}$ values above 8 in both bacterial cell suspensions and bacterial cell extracts, whereas no hydrolyzation was observed at $\mathrm{pH} 4$ (Fig. 6C and D). On the other hand, tolaasin I elimination was observed in the supernatants of bacterial cell suspensions (Fig. 6A), whereas no tolaasin I elimination was detected in the bacterial cell extracts at $\mathrm{pH} 4$ (Fig. 6B). These data suggest that, although tolaasin-hydrolyzing enzymes lost the activity at $\mathrm{pH} 4$, the factors for tolaasin adsorption exists on bacterial cells. Yang et al. (2017) reported that the adsorption of a cationic lipopeptide, brevibacillin, to the cytoplasmic membrane of Staphylococcus aureus ATCC 6538 is inhibited by exogenous lipoteichoic acid (LTA), suggesting that an ionic interaction between brevibacillin and LTA has a key role in inhibiting the adsorption of a cationic lipopeptide to Gram-positive bacterial cells. In our previous study, tolaasin I was extracted by $1 \mathrm{M} \mathrm{NaCl}$ from tolaasin-treated bacterial cells of $M$. paraoxydans NBRC $103076^{\mathrm{T}}$, which shows no tolaasin detoxification activity (Tomita et al. 2020). Based on these findings, we deduced that LTA in the cell wall of Microbacterium spp. might have an ionic interaction with cationic lipodepsipeptides, which would explain tolaasin adsorption by Microbacterium spp. This hypothesis explains our observation that tolaasin I elimination and degradation activity decreased at lower $\mathrm{pH}$, because lowering the $\mathrm{pH}$ causes the molecule to become more protonated and, hence, more positively (and less negatively) charged on the LTA (Fig. 7). Further study is needed for identification of receptors of tolaasins on bacterial cells.

Brodey et al. (1991) demonstrated that the whole structure of tolaasins is required to form an ion channel in a planar lipid bilayer by comparing tolaasin I with tolaasin-144, which lacks 3 amino acids in the peptide moiety. In this study, the resulting fragments from hydrolyzation of tolaasins at Ser6 and Leu7 were able to be detected in the $M$. foliorum 103072 cell-free extracts and the supernatants of $M$. foliorum 103072 cell suspension by LC-MS analysis (Fig. 3; Supplementary Fig. S2). Both of the hydrolyzed fragments increased in parallel up to $45 \mathrm{~min}$ in the supernatants of bacterial cell suspension (Fig. 5A) as well as in the cell-free extracts (Fig. 5B), suggesting that the resulting fragments were released from $M$. foliorum 103072 cells by hydrolyzation after adsorption of tolaasins to the bacterial cells. We previously reported that the cyclic structure of tolaasins is critical for its antimicrobial activity, especially for interaction with bacterial cells (Tomita et al. 2018). Our data suggested that the intact structure of tolaasins is important for their interaction with bacterial cells as well as for forming an ion channel in a lipid bilayer.
In conclusion, in this study, we showed that the detoxification of tolaasins by M. foliorum 103072 cells occurs though hydrolysation of tolaasins at two specific sites in the peptide moiety, and it should be noted as a novel biodegradation process of cyclic lipodepsipeptides. The hydrolases were able to be extracted from $M$. foliorum 103072 cells by a neutral detergent solution. By comparing the hydrolyzing activity of cellfree extracts and bacterial suspensions, we found evidence of tolaasin-adsorbing factors located on M. foliorum 103072 cell surfaces, which likely contribute to effective detoxification of tolaasins by M. foliorum 103072 cells.

\section{ACKNOWLEDGMENTS}

We thank A. Burch for English correction and discussion and Y. Tsujii for LC-MS/MS operation.

\section{LITERATURE CITED}

Bassarello, C., Lazzaroni, S., Bifulco, G., Lo Cantore, P., Iacobellis, N. S., Riccio, R., Gomez-Paloma, L., and Evidente, A. 2004. Tolaasins A-E, five new lipodepsipeptides produced by Pseudomonas tolaasii. J. Nat. Prod. 67:811-816.

Behrendt, U., Ulrich, A., and Schumann, P. 2001. Description of Microbacterium foliorum sp. nov., and Microbacterium phyllosphaerae sp. nov., isolated from the phyllosphere of grasses and the surface litter after mulching the sward, and reclassifcation of Aureobacterium resistens (Funke et al. 1998) as Microbacterium resistens comb. nov. Int. J. Syst. Evol. Microbiol. 51:1267-1276.

Britton, H. T. H., and Robinson, R. A. 1931. Universal buffer solutions and the dissociation constant of veronal. J. Chem. Soc. 0:1456-1462.

Brodey, C. L., Rainey, P. B., Tester, M., and Johnstone, K. 1991. Bacterial blotch disease of the cultivated mushroom is caused by an ion channel forming lipodepsipeptide toxin. Mol. Plant-Microbe Interact. 4:407-411.

D’Costa, V. M., Mukhtar, T. A., Patel, T., Koteva, K., Waglechner, N., Hughes, D. W., Wright, G. D., and De Pascale, G. 2012. Inactivation of the lipopeptide antibiotic daptomycin by hydrolytic mechanisms. Antimicrob. Agents Chemother. 56:757-764.

Goor, M., Vantomme, R., Swings, J., Gillis, M., Kersters, K., and de Ley, J. 1986. Phenotypic and genotypic diversity of Pseudomonas tolaasii and white line reacting organisms isolated from cultivated mushrooms. J. Gen. Microbiol. 132:2249-2264.

Han, H. S., Jhune, C. S., Cheong, J. C., Oh, J. A., Kong, W. S., Cha, J. S., and Lee, C. J. 2012. Occurrence of black rot of cultivated mushrooms (Flammulina velutipes) caused by Pseudomonas tolaasii in Korea. Eur. J. Plant Pathol. 133:527-535.

Hermenau, R., Kugel, S., Komor, A. J., and Hertweck, C. 2020. Helper bacteria halt and disarm mushroom pathogens by linearizing structurally diverse cyclolipopeptides. Proc. Natl. Acad. Sci. U.S.A. 117:23802-23806.

Hoefler, B. C., Gorzelnik, K. V., Yang, J. Y., Hendricks, N., Dorrestein, P. C., and Straight, P. D. 2012. Enzymatic resistance to the lipopeptide surfactin as identified through imaging mass spectrometry of bacterial competition. Proc. Natl. Acad. Sci. U.S.A. 109:13082-13087.

Hutchison, M. L., and Johnstone, K. 1993. Evidence for the involvement of the surface active properties of the extracellular toxin tolaasin in the manifestation of brown blotch disease symptoms by Pseudomonas tolaasii on Agaricus bisporus. Physiol. Mol. Plant Pathol. 42:373-384.

King, E. O., Ward, M. K., and Raney, D. E. 1954. Two simple media for the demonstration of pyocyanin and fluorescin. J. Lab. Clin. Med. 44:301-307.

Nutkins, J. C., Mortishire-Smith, R. J., Packman, L. C., Brodey, C. L., Rainey, P. B., Johnstone, K., and Williams, D. H. 1991. Structure determination of tolaasin, an extracellular lipodepsipeptide produced by 
the mushroom pathogen Pseudomonas tolaasii Paine. J. Am. Chem. Soc. 113:2621-2627.

Osdaghi, E., Martins, S. J., Ramos-Sepulveda, L., Vieira, F. R., Pecchia, J. A., Beyer, D. M., Bell, T. H., Yang, Y., Hockett, K. L., and Bull, C. T. 2019. 100 Years since Tolaas: Bacterial blotch of mushrooms in the 21st century. Plant Dis. 103:2714-2732.

Paine, S. G. 1919. Studies in bacteriosis. II. A brown blotch disease of cultivated mushrooms. Ann. Appl. Biol. 5:206-219.

Soler-Rivas, C., Jolivet, S., Arpin, N., Olivier, J. M., and Wichers, H. J. 1999. Biochemical and physiological aspects of brown blotch disease of Agaricus bisporus. FEMS Microbiol. Rev. 23:591-614.

Thorn, G., and Tsuneda, A. 1996. Molecular genetic characterization of bacterial isolates causing brown blotch on cultivated mushrooms in Japan. Mycoscience 37:409-416.

Tolaas, A. G. 1915. A bacterial disease of cultivated mushrooms. Phytopathology 5:51-55.
Tomita, S., Hirayasu, A., Kajikawa, A., Igimi, S., Shinohara, H., and Yokota, K. 2020. Adsorption of tolaasins, the toxins behind mushroom bacterial blotch, by Microbacterium spp. is insufficient for its detoxification. Curr. Microbiol. 77:910-917.

Tomita, S., Sue, M., Kajikawa, A., Igimi, S., Shinohara, H., and Yokota, K. 2018. Detoxification process of tolaasins, lipodepsipeptides, by Microbacterium sp. K3-5. Biosci. Biotechnol. Biochem. 82:1455-1458. van der Woude, A. D., Mahendran, K. R., Ummels, R., Piersma, S. R., Pham, T. V., Jiménez, C. R., de Punder, K., van der Wel, N. N., Winterhalter, M., Luirink, J., Bitter, W., and Houben, E. N. 2013. Differential detergent extraction of Mycobacterium marinum cell envelope proteins identifies an extensively modified threonine-rich outer membrane protein with channel activity. J. Bacteriol. 195:2050-2059.

Yang, X., Huang, E., and Yousef, A. E. 2017. Brevibacillin, a cationic lipopeptide that binds to lipoteichoic acid and subsequently disrupts cytoplasmic membrane of Staphylococcus aureus. Microbiol. Res. 195:18-23. 